\title{
Past and recent evolution of the Jelení potok floodplain (Opava catchment, Czech Republic)
}

\author{
VÁCLAV TREML, PETR ČERMÁK \\ Department of Physical Geography and Geoecology, \\ Faculty of Science, Charles University in Prague
}

\begin{abstract}
Floods are considered to be a crucial agent influencing the formation of the floodplain. The knowledge of the floodplain evolution can be therefore an important source of information about the past floods magnitude and frequency. Recent and past dynamics of the Jelení potok floodplain (Opava catchment) was analyzed in this study using dendrochronological and geomorphological methods. Complex structure of the floodplain was usually represented by gravels covered by distinct layer of fine-grained sediment. The beginning of the floodplain development by accumulation of fine-grained particles is estimated to be of the Medieval age (ca 900 years BP). Up to $60 \mathrm{~cm}$ of loamy silts have been deposited since that period. Lateral erosion of the channel is recently a dominant geomorphological process in the studied floodplain. The most extensive erosional landforms (bank scours, flood channels) were formed during the July 1997 flood. In addition, another two flood events were recorded based on dendrochronological markers. Recent dynamics of the Jelení potok floodplain is, however, strongly affected by human- induced transformation of the channel.
\end{abstract}

Key words: floodplain - Opava - Holocene - historical floods - fluvial geomorphology

\section{Introduction}

The landforms in temperate climate have been substantially modelled by fluvial geomorphological processes during the Holocene (Gregory et al. 2006). The most significant changes of relief occur in consequence of the flood events (Saint-Laurent 2004). The frequency of floods during the Holocene is driven mainly by climatic oscillations, landscape/landcover changes and probably also by human influences (Vandenberghe 2000; Macklin et al. 2006). Investigations of natural archives (e.g. floodplain deposits) coupled with analysis of recent fluvial processes are necessary to asses the changes of the Holocene flood dynamics. This study aims to apply the above mentioned approach on the example of Jelení potok brook (left side tributary of the Opava River, Fig. 1).

The study area represents a floodplain of a small, mid-mountain stream situated in the Central Europe. Several phases of both the increased flood activity and changes in the lowland rivers' channel patterns during the Holocene are reported from this region (Starkel 2000; Starkel et al. 2006). Periods of increased frequency of flood events were recognized in Late Glacial/Holocene turn, in 8.5-7.8; 6.6-6.0; 5.5-4.9; 4.5-4.2; 3.5-3.0; $2.8-2.7 ; 2.2-1.8 \mathrm{kY} \mathrm{BP}$, and also during the $10^{\text {th }}-11^{\text {th }}$ and $16^{\text {th }}-19^{\text {th }}$ century (Starkel 2002). 
Holocene channel patterns changed together with the changing climate, vegetation and anthropogenic pressure (Macklin et al. 2006). At the Pleistocene/Holocene transition, braided rivers and streams deposited gravel and coarse clastic sediments. Braided channel patterns were consequently transformed into meandering channels during the early Holocene. Such rivers and streams tended to incise into the valley floors during the lower and middle Holocene. The accumulation of deposits in the floodplains started in the upper Holocene due to increased sediment load in consequence of deforestation and extensive agriculture (Starkel 2000; Czudek and Hiller 2001). Flood sediments from this period are characteristic by the dominance of fine-grained particles, re-deposed clastic and gravel sediments are, nevertheless, also frequent (Opravil 1983; Ložek 2003). It should be noted, however, that flood frequency and changing channel patterns are mostly derived from the sequences of alluvial deposits of large lowland rivers and the knowledge of small streams' dynamics is considerably weaker (Dotterweich 2008). Evolution of small streams' floodplains is more influenced by local extreme events and the observed sedimentary records may not be complete. In addition, the small streams' floodplains are closely coupled with adjacent slopes (Owczarek 2008). Delivery of colluvial deposits could be thus a more significant sediment source compared to large floodplains.

The share of individual factors affecting the changes in the behavior of fluvial systems is not clearly known yet. The response of channel pattern and sediment accumulation to variable interacting processes (human impact, climatic and vegetation change) is often complex and ambiguous (Millar 2000). However, the medieval colonization of mid-mountain areas had remarkable effect on the deposition of alluvial sequences and overbank sediments (Klimek 2002; Hrádek 2006; Starkel et al. 1996; Hoffmann et al. 2008). In lowland river valleys, significant layers of fine-grained flood sediments were already deposited since the Neolithic stage (Havlíček 1991).

Lateral erosion and shifts of channels seem to be the main recent processes affecting the floodplain dynamics in mid-mountain streams in the Central Europe (Malik and Owczarek 2005; Malik 2005; Hrádek and Malik 2007; Křížek 2007). Aside from that, the recent development of channels and floodplains depends strongly on the anthropogenic transformations (e.g. Krrížek and Engel 2007). In addition, deforestation culminating at the beginning of $19^{\text {th }}$ century and consequent changes in the forest composition are considered to be significant agents enhancing erosion and increasing discharges in the East Sudetes Mts. (Klimek and Latocha 2007). Recent evolution of the river channels and floodplains in the study area was accelerated during several large floods and extreme precipitation events (Polách and Gába 1991; Štekl et al. 2001; Migoň et al. 2002). Morphological responses of the channels and floodplains to the floods were documented by Hrádek and Malik (2007) on the Desná river and by Malik and Owcarek (2005) and Malik and Matyja (2008) on the Opava River.

As mentioned above, this study aims to assess both the past and the recent floodplain dynamics on the example of the Jeleni potok brook. In particular, the main aim of the study was to answer following questions: (a) How did the floodplain react on the anthropogenic pressure in the past? - and (b) Do recent tendencies of floodplain sedimentation or erosion differ from those in the past? 


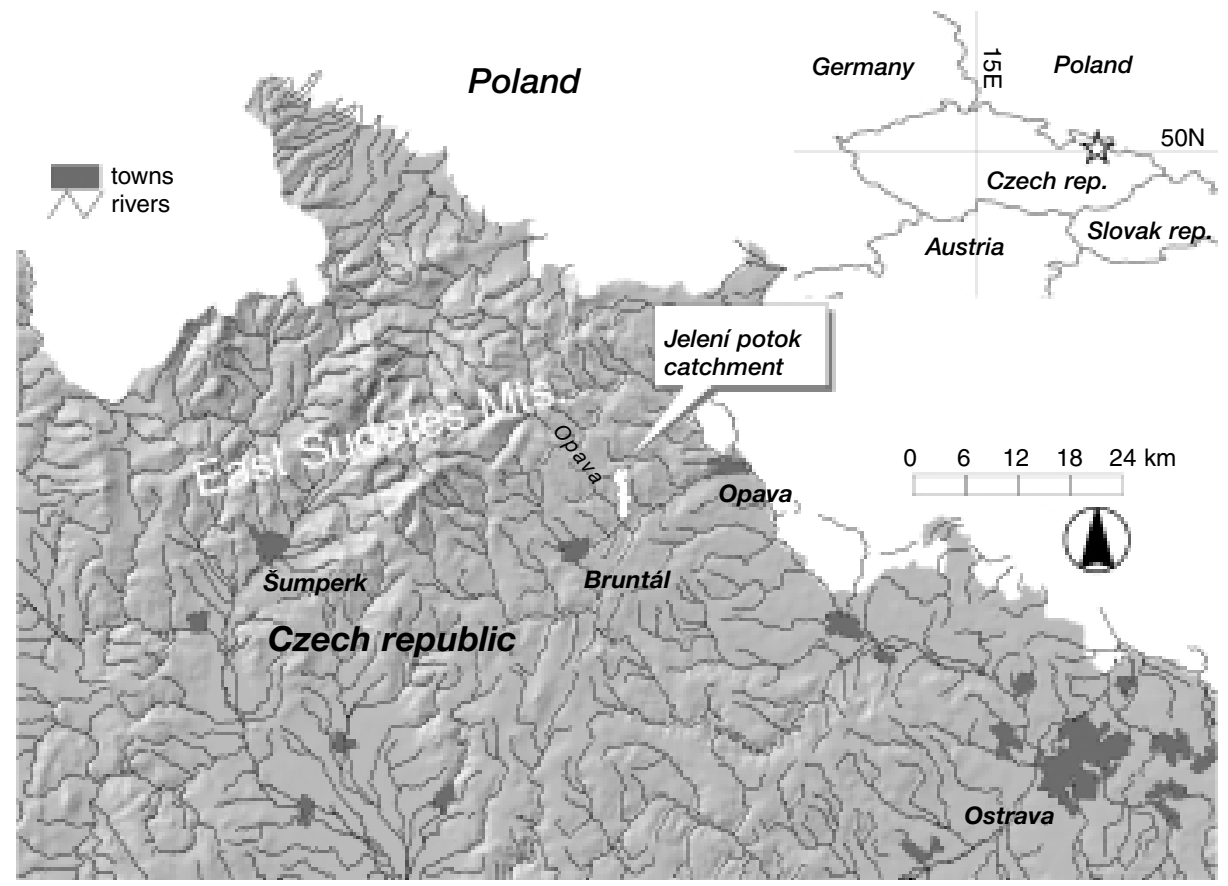

Fig. 1: Position of the study area

\section{Methods}

\section{The study area}

The area of interest is situated in the East Sudetes Mts., in the Krasovská vrchovina Upland (Nízký Jeseník Highland, Demek 1987). It is built by Carboniferous greywackes of Horní Benešov Formation (Dvořák 1996). Mean altitude of the Jelení potok catchment is $529 \mathrm{~m}$ a.s.l. and its relative relief reaches almost $240 \mathrm{~m}$. The slopes of the catchment are in average $8.1^{\circ}$ steep. Long-term annual mean temperatures oscillate around $7.3{ }^{\circ} \mathrm{C}$ (Květoň 2001). Annual precipitation sum ranges from 800 to $1000 \mathrm{~mm}$ (Tolasz 2007). Mean long-term discharge of the Opava River reaches $2.51 \mathrm{~m}^{3} . \mathrm{s}^{-1}$ (discharge gauge profile Karlovice), estimated discharge of the Jelení potok brook usually ranges between several litres and first tens of litres per second. The width of the floodplain of the Jelení potok brook ranges from $75 \mathrm{~m}$ at the lowermost part of stream to $30 \mathrm{~m}$ in the upper part of the catchment. The channel is usually incised 0.8-1.2 $\mathrm{m}$ into the floodplain deposits. The channel width varies from $1 \mathrm{~m}$ (upper course) to $3 \mathrm{~m}$ (lower course). The channel of the Jelení potok brook is largely transformed by artificial bunding of the banks using timberlogs or stone ripraps (approx. $70 \%$ of the stream length). Depth of the floodplain deposits near the valley mouth is estimated up to $2.5 \mathrm{~m}$ according to the ground penetrating radar measurements (Treml et al. 2008b). 
The floodplain is covered either by meadows (predominantly middle and upper part of catchment) or by a mosaic of meadows and alluvial forests composed of alders (Alnus incana, Alnus glutinosa) and poplars (Populus tremula).

The area of the catchment reaches 790 hectares. The forests, composed predominantly of the Norway spruce (Picea abies) plantations, prevail in the catchment (57\% of the total area). Other types of the landcover are represented by meadows and pastures (34\%) and arable land (7\%), which is situated mainly in the source area

\section{Geomorphological mapping}

Fluvial landforms in the floodplain were mapped in the scale 1:5000 using a GPS. Following categories were recognized (after Krŕžžek 2007): floodplain, alluvial cones, levees, flood channels, abandoned channels, two-stage channels, floodplain sand or gravel deposits, channel sand or gravel bars, lateral erosion marks (bank failures: slab failures, slumps, bank scours sensu Brierley and Fryirs 2005). Additional data regarding the sedimentary bodies' area, depth, texture and structure were recorded in case of the accumulation landforms. The area was measured both for erosional and accumulation landforms.

\section{Dendrochronological dating of the flood landforms}

Channel as well as floodplain segments with distinct flood-related morphological changes were identified. Trees (alder Alnus glutinosa or maple Acer platanoides) directly affected by erosion or accumulation events were selected and cored. Trees with exposed roots, injured, wounded or with inclined stem, or trees with sedimentcovered basal part of the stem were chosen. The above mentioned events are recorded in the tree ring chronology as abrupt growth changes (narrowing or widening of tree rings), formation of the reaction wood, changes in differentiation of early and late wood (Strunk 1997; Vandekerkhove et al. 2001; Gärtner et al. 2001). Both drill cores and discs were sampled from exposed roots and from stems.

Samples were processed using standard dendrochronological methods (Stokes and Smiley 1968). Average tree ring chronology was developed based on floodplain alders visually not affected by past flood events. We used this chronology to remove the influence of the effects other than floods on tree ring widths (e.g. droughts, cold vegetation season, outbreaks, etc.). Measurement of the tree ring widths and development of the tree ring chronologies was processed using TimeTable device and PAST4 software (SCIEM 2004).

Abrupt growth changes (negative pointer years or growth decreases lasting at least three years, Malik and Owcarek 2005) or significant deviations from the average chronology were recorded while checking the tree ring chronologies. The age of the erosion or accumulation event was determined according to the number of tree rings between the youngest tree ring and the first tree ring with distinct change in width or morphology. In some cases we used simple counting of tree rings to determine the age of the tree, which was the same as the minimum age of underlying surface. 


\section{Description of sedimentary profiles}

Profiles through alluvial sediments were described in order to estimate the past sedimentary environments with respect to the distance from the channel (channel, banks or levees, other parts of floodplain). The profiles were either excavated in the floodplain or adapted from natural exposures on the brook banks or abandoned channels. The sequence of the alluvial strata was then described regarding its structure and texture (sensu Kukal 1964; Miall 1996). The colour of the sediment was determined using the Munsell soil color chart. Particle size analysis was performed using laboratory sieves. Sediment sorting was visually determined according to Hubbard and Glassner (2003) (sorting categories: very well sorted, moderately sorted, poorly sorted, very poorly sorted). Clasts were classified according to their roundness into six categories: well rounded - rounded - sub-rounded - sub-angular - angular very angular (Hubbard and Glassner 2003). Roundness of twenty clasts ranging from 5 to $20 \mathrm{~cm}$ was determined for every sedimentary stratum. Other sedimentary structures were also noticed (imbrication, type of bedding). Two samples of organic matter (charcoals) were dated using AMS radiocarbon dating (Poznaň radiocarbon laboratory, samples Poz-22186, Poz-22997) in order to estimate the age of the sediments and the depositional rate.

\section{Results}

\section{Flood landforms}

Erosional landforms formed by floods prevail in the floodplain of the Jelení potok brook. Bank failures are the most common landform, widespread both in the upstream and downstream part of the floodplain (Fig. 2). More than a half of the total number of bank failures is represented by small failures with volume lower than $10 \mathrm{~m}^{3}$. Size of the most extensive bank failures reach up to $30 \mathrm{~m}$ in length (in the stream direction) and up to $5 \mathrm{~m}$ in width (perpendicular to the stream direction). Bank failures are usually represented by bank scours, which form scalloped banks. Two sections of abandoned channel were also observed. Flood channels occur predominantly in the Opava river floodplain, one flood channel - connected with a two-stage channel - was, nevertheless, found in the downstream part of the Jelení potok floodplain (Fig. 4).

Flood accumulation landforms (gravel and sand bars, sand sheets) were detected both in the channel and on the surface of the floodplain. They were spatially connected with segments of frequent occurrence of the bank failures. Thin sand or gravel covers are gradually incorporated in the floodplain surface, so in reality they would probably have significantly higher extent if mapped immediately after the flood event.

Spatial distribution of erosion and accumulation landforms is rather unequal. It results mainly from increasing discharge in the downstream part of the channel and from the character of the bank bunding. Stone ripraps, which effectively prevent lateral erosion, are often used in the middle part of the Jelení potok brook channel, where the bank failures are almost missing. 
A two-stage channel in the downstream part of Jelení potok stream was the largest mapped erosional landform (length $30 \mathrm{~m}$, width 4 to $6 \mathrm{~m}, \mathrm{~J} 1$ - Fig. 4). It had probably been formed during the 1997 flood. The second step of the channel is colonized by alders. The oldest alder germinated in 1998. Other extensive flood landforms (bank failures J4, J5) also originated during the 1997 summer flood. It is proved by the age of the trees growing on the bottom of the failure (J5) and by an abrupt growth decrease in disturbed alder situated on the margin of failure J4. Bank failures J2 (length $30 \mathrm{~m}$, maximum width $3 \mathrm{~m}$ ) and $\mathrm{J} 3$ (length $10 \mathrm{~m}$, maximum width $2.5 \mathrm{~m}$ ) were formed

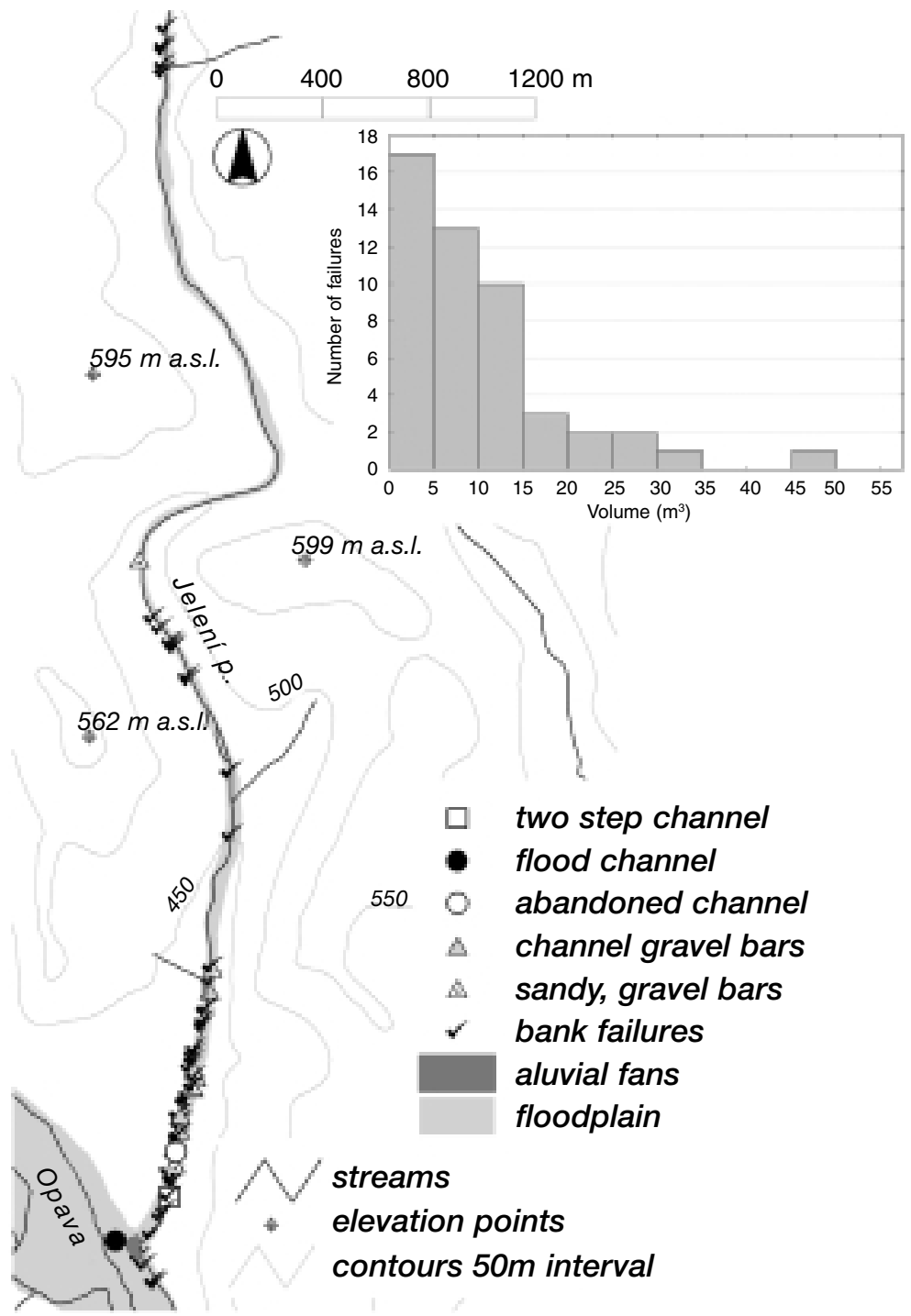

Fig. 2: Position of landforms formed by floods. Histogram shows the size distribution of the bank failures 
already before the 1997 flood. A tension wood in alder stem growing on the bank failure margin was formed between years 1989 and 1992.

Most of the dendrochronological markers of floods are dated to 1998 (Fig. 3), thus they could be ascribed to the flood event in July 1997. The early and partly also the late wood of the year 1997 was already formed and thus the reaction on disturbance was expressed in the tree ring created in the subsequent year (1998). In addition, many trees germinated on fresh surfaces in 1998. Three to four markers were also detected for years 1991 and 1988. They could be probably ascribed to a local flood in 1991 and to delayed reaction to the flood in 1986. The on-going lateral erosion on bank failures or late colonization of erosion/accumulation surfaces could explain this delay. The rest of dendrochronological markers are either solitary or double. They were probably caused rather by local evolution of the channel than by a large flood event that would have affected the whole catchment.

\begin{tabular}{|c|c|c|}
\hline Year & Tree reaction & Floods, extraordinary rainfalls \\
\hline 2007 & & \\
\hline 2006 & & \\
\hline 2005 & & \\
\hline 2004 & & \\
\hline 2003 & oo & \\
\hline 2002 & & \\
\hline 2001 & & \\
\hline 2000 & & \\
\hline 1999 & $x$ & \\
\hline 1998 & $x \times x \times \times 00000$ & \\
\hline 1997 & & \\
\hline 1996 & & \\
\hline 1995 & oo & \\
\hline 1994 & & \\
\hline 1993 & $x x$ & \\
\hline 1992 & $x$ & \\
\hline 1991 & $\times \mathrm{O}++$ & \\
\hline 1990 & ++ & \\
\hline 1989 & ++ & \\
\hline 1988 & $\times 0+$ & \\
\hline 1987 & & \\
\hline 1986 & & \\
\hline 1985 & & \\
\hline 1984 & $x$ & \\
\hline 1983 & & \\
\hline 1982 & & \\
\hline 1981 & & \\
\hline 1980 & & \\
\hline 1979 & & \\
\hline 1978 & $\mathrm{o}$ & \\
\hline 1977 & $\mathrm{O}$ & \\
\hline 1976 & & \\
\hline 1975 & & \\
\hline 1974 & & \\
\hline 1973 & & \\
\hline 1972 & & \\
\hline 1971 & & \\
\hline 1970 & & \\
\hline$\times \ldots$ beginning of growth & & \\
\hline $\mathrm{o} \ldots$ growth reduction & & \\
\hline$+\ldots$ tension wood & & \\
\hline
\end{tabular}

Fig. 3: Dendrochronological markers of flood-driven disturbances. The years with floods and extraordinary rainfalls are listed according to Polách and Gába (1998) and Štekl et al. (2001) 


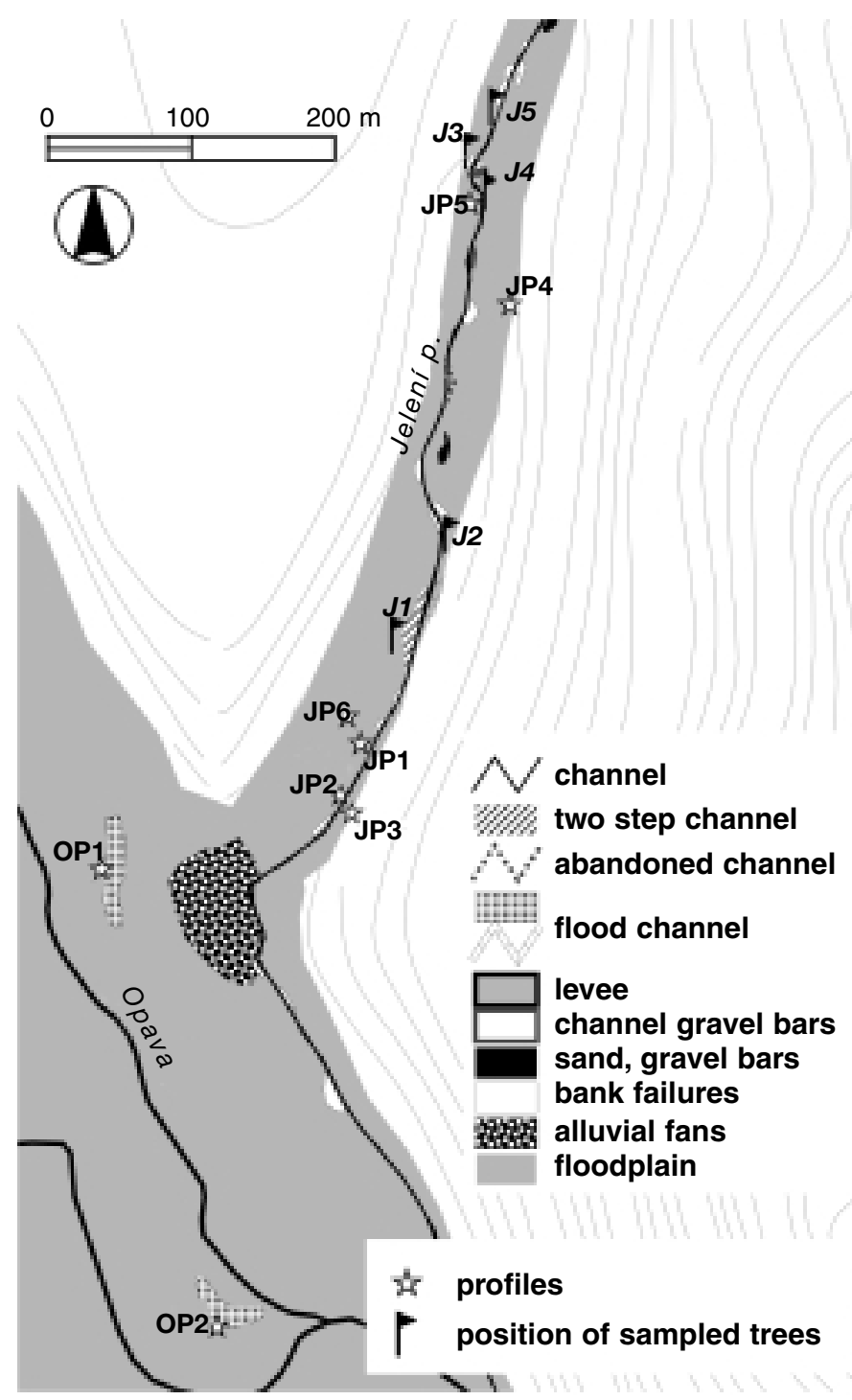

Fig. 4: Detailed map of the downstream part of the Jelení potok floodplain

\section{Alluvial sequences}

Eight sedimentary profiles were described in the floodplain of the Jelení potok brook and in the adjacent floodplain of the Opava River. Profiles JP1, JP2, JP3 and JP6 are situated nearby the Jelení potok valley mouth (Fig. 4).

Flood silts with gravel $(0-17 \mathrm{~cm})$ and a distinct organic layer $(30-39 \mathrm{~cm})$ were identified on Profile JP1 (layers "a" - "d", Fig. 5). Fine-grained organic layer (loamy 

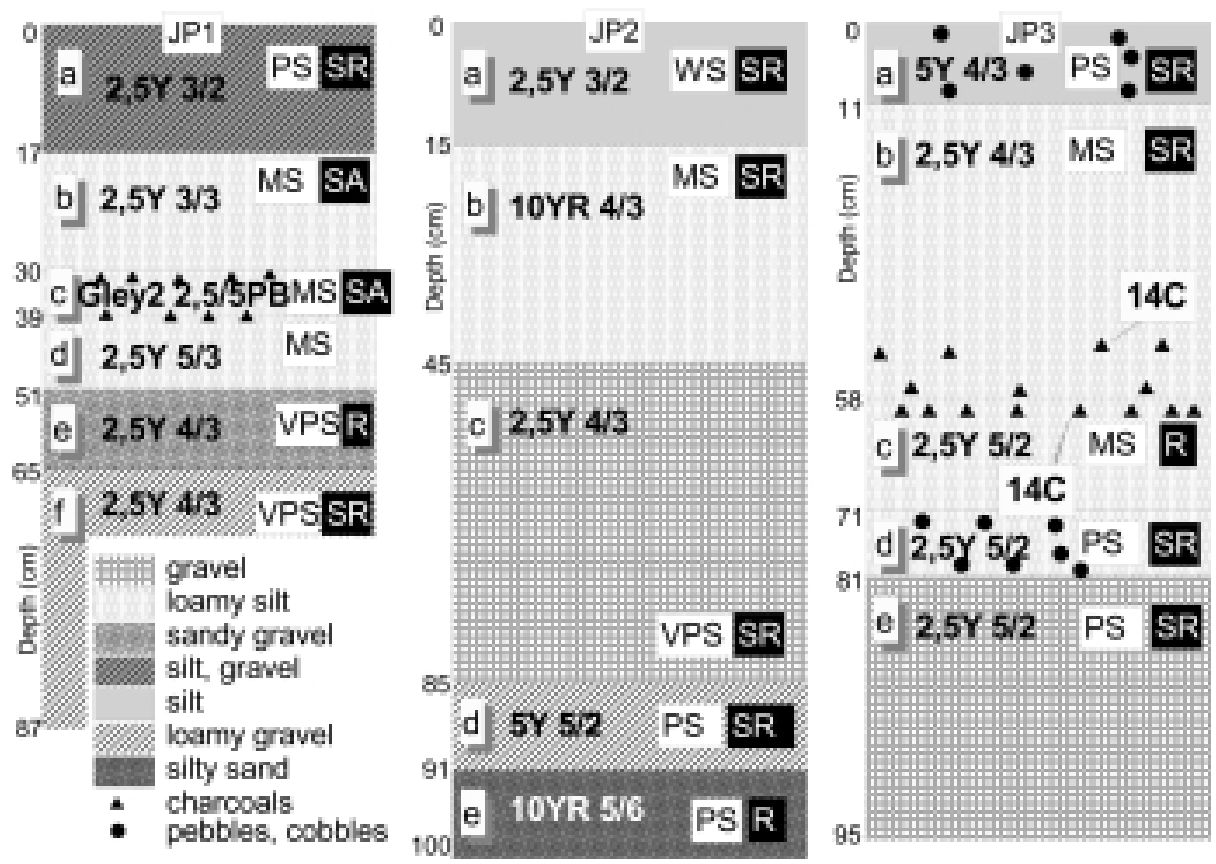

Fig. 5: Sedimentary profiles JP1, JP2 and JP3. Munsell chart colour codes are written within the individual strata. Abbreviations in the boxes: white box - WS-well sorted, MS-moderately sorted, PS-poorly sorted, VPS-very poorly sorted; black box - WR-well rounded, R-rounded, SR-subrounded, SA-subangular

silt, "c") could be interpreted as a backswamp deposit which was gradually overlaid by flood sediments. Charcoals sporadically occur within the organic layer. Lower part of the profile $(51-80 \mathrm{~cm})$ represents the channel gravels with horizontally deposed cobbles (longer axis length from 20 to $25 \mathrm{~cm}$ ). Silty floodplain deposits grading into sands and gravels were detected on Profile JP2. This alluvial sequence could be explained as overbank (fine-grained) sediments deposited on channel gravels at the bottom of the profile.

Overbank fine-grained sediments can also be seen on the JP3 profile. Significant positive gradation of the sediment can be observed in the "d" layer (depth 71-81 cm). It probably results from a gradual filling of an abandoned channel, which is represented by coarse gravel and pebbles $(81-90 \mathrm{~cm})$. The charcoals occur frequently between 45 and $59 \mathrm{~cm}$ of depth. Two charcoals were dated using the radiocarbon method $(59 \mathrm{~cm}$

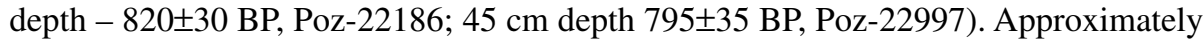
$60 \mathrm{~cm}$ thick layer of fine-grained sediments have been deposed during last 900 years. It corresponds to the average depositional rate of $0.5 \mathrm{~mm}$ per year. With respect to the narrow time span between the two deposed charcoals, it seems that the whole section of the profile with the charcoals sedimented either during one event or within a very short period. The charcoals are situated in the basal part of the flood silts. Silt layer is distinctly separated from the underlying gravels. Since this boundary is pronounced also in the other analyzed profiles, it may represent a similar period. 
The JP4 sediment profile is situated in higher distance upstream from the valley mouth. A distinct layer of imbricated cobbles ("b") was detected here between two layers of silty deposits ("a", "c", Fig. 6). Such clastic bedding is often found in the levees. On the other hand, silts are usually deposed in the floodplain far from the channel, i.e. under low flow velocities. Basal part of the profile ("e") probably represents the channel gravels and pebbles.

Silty deposits with frequent horizontally oriented cobbles and pebbles are exposed in the profile JP5 (Fig. 6). Sand fraction is practically absent in the upper part of the sediment profile $(0-70 \mathrm{~cm}$ depth). With respect to the size of the clasts, the described sediments were probably deposited either in the proximity of the channel or in a floodchannel.

The profile JP6 is situated close to the Jelení potok brook valley mouth. Compared to the other sedimentary profiles, the JP6 profile was excavated further from the current channel (ca $40 \mathrm{~m}$ ). Uppermost layers ("a", "b") are built by flood silts to loams, which were probably deposited under low flow velocities in the floodplain. Lower layer consists of gravels, pebbles and cobbles deposited probably within the channel or in its proximity (imbrication). Since the clasts are generally less rounded, they could be partly transported from adjacent slopes.

Two sedimentary profiles (OP1, OP2, Fig. 7) expose alluvial sequences of the Opava river floodplain. A $90 \mathrm{~cm}$ thick layer of silty loam ("a") was described in the profile OP1. Underlying deposits are built by coarse to middle gravel and horizontally oriented pebbles of size ranging from $5.3 \mathrm{~cm}$ ("b") to $7.6 \mathrm{~cm}$ ("c") in the longest axis. It can be suggested that the lower part of the profile ("b", "c") was deposited in the channel, whereas the overlying loamy silts sedimented under low flow velocities in the floodplain. The profile is situated on the bank of an abandoned flood channel formed during the 1997 flood.
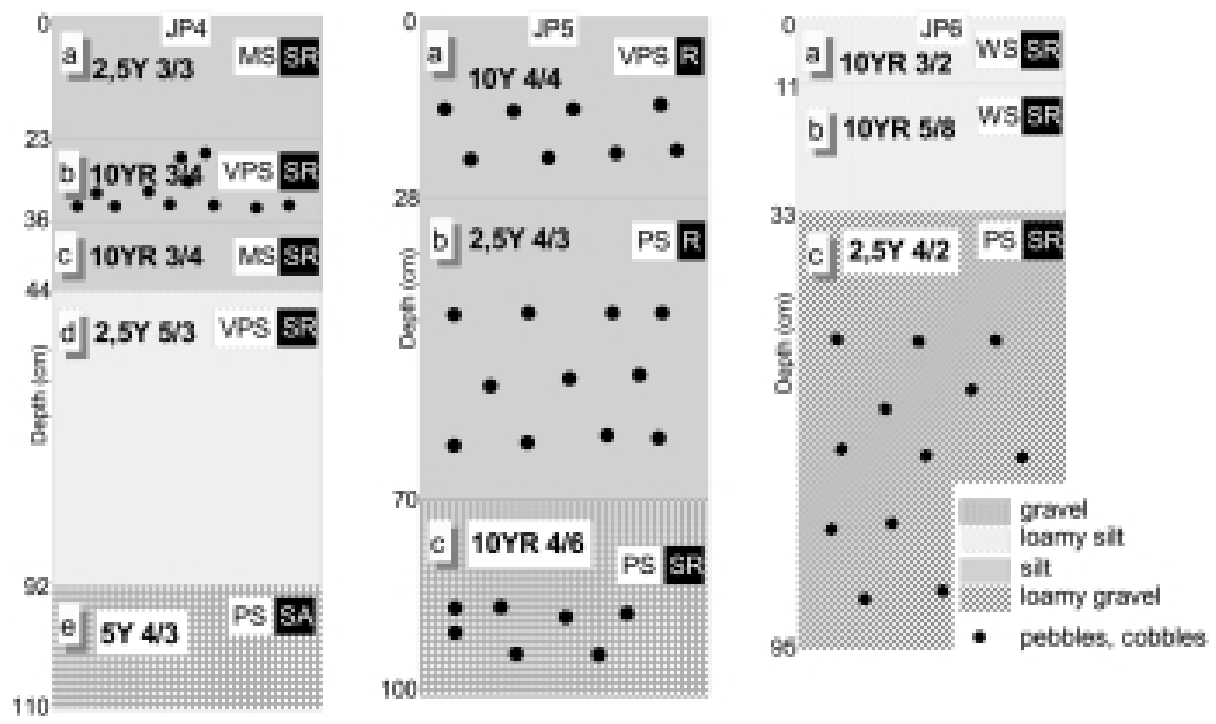

Fig. 6: Sedimentary profiles JP4, JP5 and JP6. For abbreviations see Fig. 5 

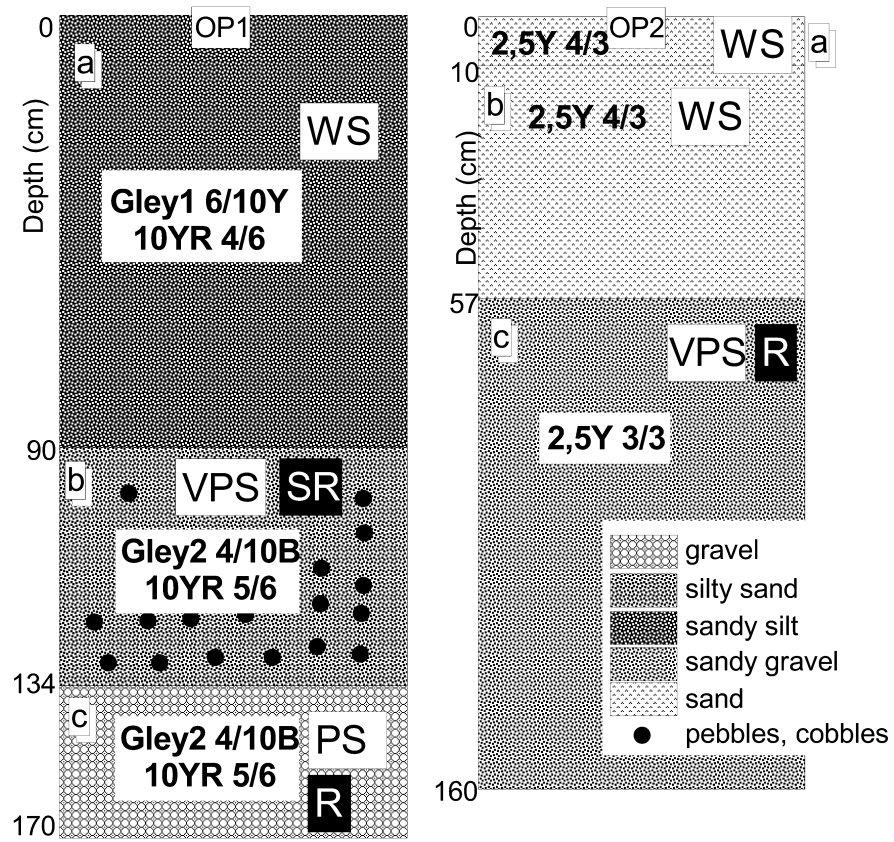

Fig. 7: Sedimentary profiles OP1, OP2. For abbreviations see Fig. 5

The OP2 profile was exposed in a bank of another abandoned flood channel formed in 1997. It is situated $20 \mathrm{~m}$ from the active channel of the Opava river. It contains both the sediments deposed in the vicinity of the channel ("b"), probably under higher flow velocity, and the sediments deposited within the channel ("c"). Middle to fine-grained sands in " $b$ " layer have pronounced ripple bedding, which indicates deposition under higher flow velocity and thus in the channel or in its immediate vicinity. Those sediments belong probably to the levee developed on the right side of the Opava river channel.

\section{Discussion}

Bank failures were the most frequent flood-influenced landforms in the study area. They were represented mostly by bank scours, which form scalloped banks at sites where the channel direction or flow speed abruptly changes. Nevertheless, many of them occur even in the straight sections of the channel. It gives evidence of nonequilibrium status of the channel, the course of which was artificially transformed in the past. According to old maps, the channel was straightened probably at the turn of the $18^{\text {th }}$ and $19^{\text {th }}$ century. Another transformation of the stream course and the transverse profile was performed during eighties of the last century (Lesy ČR, pers. comm.). Reverse changes in the stream course could be expected if the detected flooddriven changes in the channel morphology will continue with similar intensity as 
recently. The changes in the stream course are already apparent as there are some sections with abandoned channels or with flood channels. Not only erosional landforms, but also young accumulation flood-induced landforms are present in the studied floodplain. Nevertheless, they are smaller both in number and in the extent. Thin sand and gravel accumulations are being quickly incorporated into the floodplain and thus become indistinct shortly after a flood (Křížek and Engel 2007). In this context, it is impossible to assess whether there are recently significant tendencies to the channel incision or to the aggradation of the floodplain. We believe, however, that the channel incision may be advantaged due to the overall shift of the land-cover type from arable land to forests and grasslands and thus to corresponding reduction of the source areas for soil erosion (Bravard et al. 1997). It could be also concluded that the recent lateral erosion of the Jelení potok channel is quite intensive despite its extensive man-induced transformation.

The most extensive erosional landforms were formed during the July 1997 flood. It confirms its extraordinary significance for the recent floodplain evolution (Hrádek 2000). Nevertheless, some other events were recorded using dendrochronological markers. The floods in 1991 and probably in 1986 might have had a strong geomorphological effect, since some of then created landforms have not yet been destroyed by subsequent floods. Synchronous markers of considerable floods or precipitation events were also detected in neighbouring catchments (Malik and Owczarek 2007; Hrádek and Malik 2007). Older records of floods were not observed due to the dominance of relatively young growths of alders in the studied area. The 1997 flood was recorded even in the tree ring chronologies of trees growing quite far from the stream, which indicates the significant and relatively long-term effects of this flood, probably due to high groundwater level.

Long-term tendency of the floodplain to the aggradation during the upper Holocene (Nanson and Croke 1992) was clearly visible also in the floodplain of the Jelení potok brook. Several types of deposits were detected in exposed alluvial sequences. Channel gravels and pebbles were usually found in basal parts of the described profiles. Flood loams to silts or bedded sands were deposited on these channel sediments. The depth of the fine-grained (flood) sediments ranges between 30 and $60 \mathrm{~cm}$. Corresponding deposits in the floodplain of the Opava River were significantly thicker (up to $90 \mathrm{~cm}$ ). The last important period of flood sediment deposition started during the Medieval colonization of the mid-mountain areas (Opravil 1983; Klimek 2002; Ložek 2003; Dotterweich 2008). According to the radiocarbon dating of the charcoals, an increase in sediment deposition is also recorded in the study area during this period. Nevertheless, the deposition of fine-grained sedimentary unit should not be necessarily related to the charcoal age, since this age could indicate only colonization of surrounding landscape. Although charcoals' age probably marks only maximum age of the deposits, we believe that those deposits are linked with the Medieval colonization of the study area. Charcoals are widespread within a distinct sandy layer, therefore they were deposited together with the fluvial sand. Their age is very close to the beginning of the colonization of study area (beginning of $13^{\text {th }}$ century, Zuber 1966). The depth of the fine-grained sediments varies with respect to the position in the floodplain and, naturally, with respect to the stream order. Detected fine grained sediment thickness 
ranges from 0.3 to $0.8 \mathrm{~m}$ in Jelení potok floodplain, and it reaches almost $1.3 \mathrm{~m}$ in adjacent part of Opava floodplain. The depth of the Medieval flood loams and silts is significantly higher in the downstream part of the Opava River floodplain, where it reaches up to $2 \mathrm{~m}$ (Opravil 1983). Morphologically pronounced alluvial fans were formed probably during the same period (Klimek 2007; Hrádek 2006). Deposition of thick flood deposits is linked with a complex, human-induced environmental changes in the study area. Abrupt deforestation and erosion events are recorded even in the uppermost parts of the neighbouring Hrubý Jeseník Mts. (690 to $520{ }^{14} \mathrm{C}$ years BP, Hošek 2007; Treml et al. 2008a).

The channel deposits detected far from the recent position of the stream give evidence of the past channel migration. Channel gravels and pebbles were usually (re)deposited directly under the flood silts. Gravels and pebbles belong to the fluvial facies, which have probably been deposited since the end of the last glacial (e.g. Czudek 2005). These deposits sedimented either within braided rivers or as channel deposits within meandering rivers. The last period of increased lateral migration of large rivers was recorded between 2000 and 500 BP (Starkel 2002). It could also be the period of the last intensive re-deposition of the detected gravels and pebbles.

The sediments, deposited in the close vicinity of the channel, reach maximum thickness up to $60 \mathrm{~cm}$ in the surroundings of Opava river. They were deposited during the 1997 flood. However, despite their significant thickness they do not form any morphologically pronounced levee.

According to the above mentioned findings, it could be concluded that ascertained evolution of the studied floodplains is in agreement with the depositional patterns in other catchments within the East Sudetes and within the lower course of the Opava River. It proves an extensive human-induced environmental change of the East Sudetes during the Medieval period.

\section{Conclusions}

The floodplains belong to the unique archives that record both natural and humaninduced environmental changes. The evolution of the Jelení potok floodplain conforms to the depositional patterns known from other mid-european upland brooks. A deposition and redeposition of coarse sediments under the conditions of intensively migrating channel has changed into intensive accumulation of silts during the Medieval period. The Medieval colonization probably quickly affected the whole area ranging from middle elevations (studied catchment) to the uppermost parts of the neighbouring Hrubý Jeseník Mts. An abrupt change of the environmental conditions resulted in the deposition of predominantly fine-grained sediments whose thickness depends on their position within the floodplain. Up to $60 \mathrm{~cm}$-thick layer of sediments was probably deposited in the Jelení potok floodplain since the mentioned Medieval period. It is suggested that the recent sediment input into the floodplain is lower because the major part of the catchment area is covered by forests or grasslands. Flood-originating landforms indicating the increased lateral erosion (bank failures, flood channels) are common in the floodplain of the Jelení potok brook. Most of them 
were created during the July 1997 flood. Some of the recent erosional landforms were formed earlier, probably during the 1991 and 1986 flood events. Channel dynamics has been, however, strongly influenced by artificial changes in the stream course. Widespread marks of lateral erosion indicate that the active channel of the Jelení potok brook is out of its dynamic equilibrium state.

\section{Acknowledgements}

This research would not have been possible without the support of grant project MŽP VaV SM/2/57/05 and research project MSM 0021620831. Both anonymous reviewers are acknowledged for their suggestions and comments.

\section{References}

BRAVARD, J.P., AMOROS, C., PAUTOU, G., BORNETTE, G., BOURNAUD, M., DES CHATELLIERS, M., GIBERT, J., PEIRI, J.L., PERRIN, J., TACHET, H. (1997): River incision in southeast France: Morphological phenomena and ecological effects. Regulated rivers: Research and Management, 13, 75-90.

BRIERLEY, G. J., FRYIRS, K.A. (2005): Geomorphology and river management. Malden, Blackwell publishing.

CZUDEK, J., HILLER, A. (2001): Vývoj údolní nivy řeky Odry v Ostravské pánvi. Geografie 106 (2), 94-99.

CZUDEK, J. (2005): Vývoj reliéfu krajiny České republiky v kvartéru. Brno, Moravské zemské muzeum.

DEMEK, J. (ed.) (1987): Hory a nížiny. Praha, Academia.

DVOŘÁK, J. (1996): Geologická mapa ČR, List 15-31, Bruntál. Praha, Český geologický ústav.

DOTTERWEICH, M. (2008): The history of soil erosion and fluvial deposits in small catchments of central Europe: Deciphering the long-term interaction between humans and the environment - A review. Geomorphology 101, 192-208.

GÄRTNER, H., SCHWEINGRUBER, F.H., DIKAU, R. (2001): Determination of erosion rates by analysing structural changes in the growth pattern of exposed roots. Dendrochronologia 19 (1), 81-91.

GREGORY, K.J., BENITO, G., DIKAU, R., GOLOSOV, V., JONES, A., MACKLIN, M., PARSONS, A.J., PASSMORE, D.G., POESEN, J., STARKEL, L., WALLING, D.R. (2006): Past hydrological events related to understanding global change: An ICSU research project. Catena 66 (1-2), 2-13.

HAVLÍČEK, P. (1991): The Morava river basin during the last 15000 years. In: Starkel, L., Gregory, K.J., Thornes, J.B. (eds.) Temperate palaeohydrology, fluvial processes in the temperate zone during the last 15000 years, 320-334, Chichester, John Wiley \& Sons.

HOFFMANN, T., LANG, A., DIKAU, R. (2008): Holocene river activity: analysing ${ }^{14} \mathrm{C}$-dated fluvial and colluvial sediments from Germany. Quarternary Science Reviews 27 (21-22), 2031-2040.

HOŠEK, J. (ed.) (2007): Vliv porostů borovice kleče (Pinus mugo) na př́rodní podmínky Hrubého Jeseníku a Králického Sněžníku. Závěrečná zpráva z projektu VaV SM/6/70/05. Praha, MŽP.

HRÁDEK, M. (2000): Geomorfologické účinky povodně 1997 na území Moravy a Slezska. Geografický časopis 4 (52), 303-321.

HRÁDEK, M. (2006): Př́činy a následky ničivých povodní během kolonizace vrchovin ve 13. a 14. stol. In: Smolová, I. (ed.): Geomorfologické výzkumy v roce 2006, 60-64. Olomouc, Univerzita Palackého.

HRÁDEK, M., MALIK, I. (2007): Dendrochronological records of the floodplain morphology transformation of Desná river valley in the last 150 years, the Hrubý Jeseník Mts. (Czech Republic). Moravian Geographical Reports 15 (3), 2-10.

HUBBARD, B., GLASSNER, N.F. (2003): Field techniques in glaciology and glacial geomorphology. Chichester, Wiley.

KLIMEK, K. (2002): Human-induced overbank sedimentation in the foreland of the Eastern Sudety mountains. Earth Surface Processes and Landforms 27, 391-402. 
KLIMEK, K. (2007): Environmental causes and geomorphic record of Early Medieval colonization: Southwestern margin of the Rybnik plateau and the neighbouring Odra valley. Geomorphologia Slovaca et Bohemica 2, 5-13.

KLIMEK, K., LATOCHA, A. (2007): Response of small mid-mountain rivers to human impact with particular reference to the last 200 years; Eastern Sudetes, Central Europe. Geomorphology 92, 147-165.

KŘíŽEK, M. (2007): Údolní niva jako geomorfologický fenomén. In: Langhammer, J. (ed.) Povodně a změny v krajině. Praha: Univerzita Karlova, p. 217-230.

KŘ́ǏŽEK, M., ENGEL, Z. (2007): Geomorphological consequences of the 2002 flood in the Otava river drainage basin. Acta Universitatis Carolinae, Geographica 38 (2), 125-138.

KUKAL, Z. (1964): Geologie recentních sedimentů. Praha. Nakl. Čs. Akad. Věd.

KVĚTOŇ, V. (2001): Normály teploty vzduchu na území České republiky v období 1961-1990 a vybrané teplotní charakteristiky období 1961-2000. Praha, Národní klimatický program.

LOŽEK, V. (2003): Naše nivy v proměnách času: Vznik a vývoj dnešních niv. Ochrana prírody 58 (4), 101-106.

MACKLIN, M.G., BENITO, G., GREGORY, K.J., JOHNSTONE, E., LEWIN, J., MICHCZYNSKA, D.J., SOJA, R., STARKEL, L., THORNDYCRAFT, V.R. (2006): Past hydrological events in the Holocene fluvial record of Europe. Catena 66, 145-154.

MALIK, I. (2005): Rates of lateral channel migration along the Mala Panew River (southern Poland) based on dating riparian trees and Coarse Woody Debris. Dendrochronologia 23, 29-38.

MALIK, I., OWCAREK, P. (2005): Wykorzystanie odslonietych korzeni drzew do okreslenia przebiegu erozji zboczy dolin I dostawy zwietrzelin do koryt rzek górskich (Sudety wschodnie). Czasopismo Geograficzne 76 (3), 101-116.

MALIK, I., OWCAREK, P. (2007): Dendrochronologiczny zapis erozji koryt potoków gorskich w sasiedztwie zapór przeciwrumowiskowych na przykladzie Černego potoku (Jeseniki - Sudety Wscgodnie). Przeklad Geograficzny 79 (2), 313-334.

MALIK, I., MATYJA, M. (2008): Bank erosion history of a mountain stream determined by means of anatomical changes in exposed tree roots over the last 100 years (Bílá Opava Eiver - Czech Republic). Geomorphology 98, 126-142.

MIGOÑ, P., HRÁDEK, M., PARZÓCH, K. (2002): Extreme events in the Sudetes Mountains, their longterm geomorphic impact and possible controlling factors. Studia Geomorphologica Carpatho-Balcanica 36, 29-49.

MIALL, A.D. (1996): The geology of fluvial deposits: sedimentary facies, basin analysis, petroleum geology. Berlin-Heidelberg, Springer.

MILLAR, R.G. (2000): Influence of bank vegetation on alluvial channel patterns. Water Resources Research 36 (4), 1109-1118.

NANSON, G.C., CROKE, J.C. (1992): A genetic classification of floodplains. Geomorphology 4, 459-486.

OPRAVIL, E. (1983): Údolní niva v době hradištní. Studie Archeologického ústavu ČSAV v Brně 9. Praha, Academia.

OWCZAREK, P. (2008): Hillslope deposits in gravel-bed rivers and their effects on the evolution of alluvial channel forms: A case study from the Sudetes and Carpathian Mountains. Geomorphology 98, 111-125.

POLÁCH, D., GÁBA, Z. (1991): Historie povodní na šumperském a jesenickém okrese. Severní Morava 75, $3-28$.

SAINT-LAURENT, D. (2004): Paleoflood hydrology: an emerging science. Progress in Physical Geography 28 (4), 531-543.

SCIEM (2004): PAST V4 - Personal analysis system for treering research - instruction manual. Sciem, Wien.

STARKEL, L. (2000): Change in frequency of extreme events as the indicator of climatic change in the Holocene. Geolines 11, 32-35.

STARKEL, L. (2002): Change in the frequency of extreme events as the indicator of climatic change in the Holocene (in fluvial systems). Quarternary International 91, 25-32.

STARKEL, L., KALICKI, T., KRAPIEC, M., SOJA, R., GEBICA, P., CZYŹOWSKA, E. (1996): Hydrological changes of valley floors in upper Vistula basin during late Vistulian and Holocene. Geographical Studies 9, 7-128.

STARKEL, L., SOJA, R., MICHCZYNSKA, D. J. (2006): Past hydrological events reflected in Holocene history of Polish rivers. Catena 66, 24-33. 
ŠTEKL, J., BRÁZDIL, R., KAKOS, V., JEŽ, J., TOLASZ, R. (2001): Extrémní denní srážkové úhrny na území ČR v období 1879-2000 a jejich synoptické př́̌ciny. Praha, Národní klimatický program.

STOKES M.A., SMILEY T.L. (1968): An introduction to tree-ring dating. Chicago, University of Chicago Press.

STRUNK, H. (1997): Dating of geomorphological processes using dendrogeomorphological methods. Catena $31,137-151$

TOLASZ, R., MÍKOVÁ, T., VALERIÁNOVÁ, A., VOŽENÍLEK, V. (eds.) (2007): Atlas podnebí Česka. Praha, Český hydrometeorologický ústav, Univerzita Palackého v Olomouci.

TREML, V., JANKOVSKÁ, V., PETR, L. (2008a): Holocene dynamics of the alpine timberline in the High Sudetes. Biologia 63 (1), 73-80.

TREML, V., ENGEL, Z., ČERMÁK, P., KŘǏŽEK, M. (2008b): Dynamika údolní nivy na př́ikladu Cikánského potoka (povodí Blanice) a Jeleního potoka (povodí Opavy). In: Langhammer, J. (ed.), Údolní niva jako prostor ovlivňující průběh a následky povodní, Praha, Přf UK, 229-243.

VANDEKERRCKHOVE, L., MUYS, B., POESEN, J., DE WEERDT, B., COPPÉ, N. (2001): A method for dendrochronological assessment of medium-term gully erosion rates. Catena 45, 123-161.

VANDENBERGHE, J. (2000): Climate impact on river processes, landforms and deposits in the Last Glacial. Geolines 11, 30-32.

ZUBER, R. (1966): Jesenicko v období feudalismu do roku 1848. Ostrava, Profil.

\section{Résumé}

\section{Dřívější a současný vývoj nivy Jeleního potoka (povodí Opavy)}

Údolní niva Jeleního potoka (levostranný př́tok Opavy) byla zkoumána za účelem zjišstění aktuální i historické dynamiky tohoto toku. Metodický př́stup byl založen na dendrochronologickém datování erozních a akumulačních tvarů vznikajících při povodňových událostech. Datování bylo doplněno popisem nivních sedimentů a charakteristikou prostředí, ve kterém se tyto sedimenty ukládaly.

Charakter sedimentace $\mathrm{v}$ nivě Jeleního potoka odpovídá ostatním nivám podhorských tokủ ve střední Evropě. Nejdříve byly uloženy štěrky v podmínkách intenzivně migrujícího koryta a tento typ sedimentace se změnil během středověku na sedimentaci povodňových hlín s převládající písčitou až prachovou složkou. Středověká kolonizace představovala velmi zásadní změnu př́rodních podmínek v širším okolí studované oblasti, a to od středních poloh (vlastní studované povodí) až po nejvyšší partie sousedícího Hrubého Jeseníku. Rychlé odlesnění a zavedení hospodaření na orné půdě vyústilo v sedimentaci povodňových hlín $\mathrm{v}$ mocnostech až kolem $60 \mathrm{~cm}$. Mocnost jemnozrnných sedimentů je však v rámci údolní nivy vysoce variabilní. Aktuální ukládání sedimentů v nivě je pravděpodobně méně intenzivní než v minulosti, a to zejména proto, že naprostá většina povodí je pokryta bud’ travními porosty nebo lesy.

Z erozních tvarů reliéfu vytvořených povodněmi jsou v nivě Jeleního potoka nejhojněji zastoupeny břehové nátrže a povodňová koryta. Tyto tvary, nejčastěji vytvořené během povodně v roce 1997, svědčí o zvýšené boční erozi. Některé $\mathrm{z}$ erozních tvarů byly vytvořeny již dříve, a to během povodňových událostí v letech 1991 a 1986.

Dynamika koryta Jeleního potoka je silně poznamenána antropogenními úpravami jeho trasy, podélného i přičného profilu koryta. Velký počet erozních tvarů ukazuje, že toto uměle upravené koryto jeví zvýšenou nestabilitu a není ve stavu dynamické rovnováhy.

Václav Treml

Department of Physical Geography and Geoecology, Faculty of Science, Charles University in Prague

Albertov 6 ,

12843 Prague 2

Czech Republic

e-mail:treml@natur.cuni.cz.

phone: +420221995524 